Asian J Agric \& Biol. 2021(4).

\title{
Importance of flies for Mangifera indica cv. Kent (Anacardiaceae) pollination and fruit set in the Sudano-Sahelian area of Cameroon
}

\author{
Michelson Azo'o Ela1*, Aïne Bidiki Bouba², Pélagie Djenatou ${ }^{3}$, Fernand-Nestor Tchuenguem Fohouo ${ }^{4}$ \\ ${ }^{1}$ Department of Biological Sciences, Faculty of Science, University of Maroua, Maroua, Cameroon \\ ${ }^{2}$ Department of Life and Earth Sciences, Higher Teachers' Training College, University of Maroua, Maroua, Cameroon \\ ${ }^{3}$ Maroua Regional Agricultural Research Center for the Development CRRA-M, Institute of Agricultural Research for the \\ Development, Maroua, Cameroon \\ ${ }^{4}$ Department of Biological Sciences, Faculty of Science, University of Ngaoundere, Ngaoundere, Cameroon
}

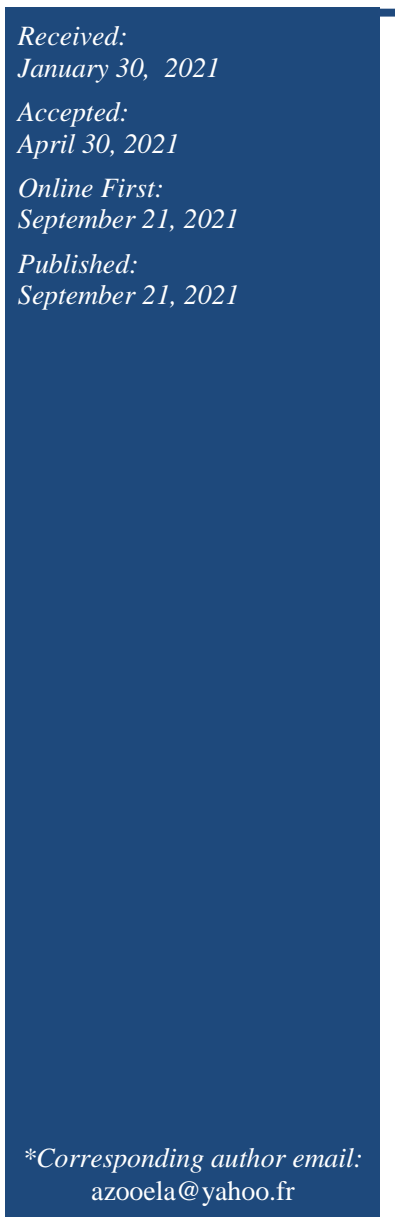

\section{Abstract}

Field experiments were conducted to find out the floral activity of insects on Mangifera indica $\mathrm{cv}$. Kent (Anacardiaceae) for assessing the impact on pollination and fruit set in 2018/2019 and 2019/2020 seasons. Two treatments were made with open-pollinated flowers (treatment A) and secondly bagged panicles (treatment B). The diversity of the entomofauna and certain foraging parameters were recorded in treatment $\mathrm{A}$ and a comparison of fruit set was made for both treatments. Twenty-six insect species were recorded overall. Bees were sporadic with a relative abundance of only $<9 \%$. The order Diptera with a relative abundance of $89.35 \%$ was the most species-rich. Chrysomya putoria (Calliphoridae) and an undetermined species belonging to the genus Sarcophaga (Sarcophagidae) were constant species. These flies were active daily during study with a peak of activity at the 7:00-10:00 a.m. recorded time interval. Flower visits by flies were noted as $89 \%$ for nectar harvesting and $11 \%$ for pollen collection. During their foraging activity, flies induced the pollination of hermaphroditic flowers which resulting in an improvement in mango fruit yields. The rate of mature fruit per panicle was $0 \%$ in treatment B during both years, with $1.07 \%$ in $2018 / 2019$ and $1.85 \%$ in $2019 / 2020$ in treatment A. Flies are here identified as essential flower-visiting insects and pollinators of $M$. indica which guaranteed fruiting of this crop in Maroua (Cameroon).

Keywords: Mango tree, Diptera, Yield, Self-incompatibility, Cross pollination

\section{How to cite this:}

Azo'o Ela M, Bouba AB, Djenatou P and Fohouo FNT, 2021. Importance of flies for Mangifera indica cv. Kent (Anacardiaceae) pollination and fruit set in the SudanoSahelian area of Cameroon. Asian J. Agric. Biol. 2021(4): 202102062. DOI: https://doi.org/10.35495/ajab.2021.02.062

This is an Open Access article distributed under the terms of the Creative Commons Attribution 3.0 License. (https://creativecommons.org/licenses/by/3.0), which permits unrestricted use, distribution, and reproduction in any medium, provided the original work is properly cited.

\section{Introduction}

Pollination services are known to provide substantial benefits to human populations and agriculture in particular (Breeze et al., 2011). Honey bees (Apis mellifera) are often assumed to provide the majority of pollination services to agriculture (Klein et al., 2007), but recent studies cast doubt on this long held-belief (Breeze et al., 2011). It has been demonstrated that other insect groups constitute important pollinators 
(Larson et al., 2001). Wild pollinators are very diverse and exhibit various traits (Fontaine et al., 2006). Flies are known to be the prominent flower visitors and pollinators of several crops (Rader et al., 2009). For instance, in the UK, two hoverfly species Eupeodes latifasciatus and Episyrphus balteatus (Diptera: Syrphidae) increased strawberry yields by over $70 \%$ and doubled the proportion of marketable fruit (Hodgkiss et al., 2018).

Despite the growing appreciation of flies as pollinators, there is a lack of community-wide studies of flower visitation and hence, their contribution in pollinating services in an agronomic context remains largely unexplored (Larson et al., 2001). In sub-Saharan Africa, the relative contribution of flies in the study of plant-pollinator networks, in particular, remains in its infancy and the lack of studies impedes their management in an agro-ecological context.

The mango tree Mangifera indica $\mathrm{L}$. is a cultivated plant species native to South Asia, particularly in India and Burma (Singh et al., 2005). It was introduced to Africa in the $16^{\text {th }}$ century by Arabs and is widely cultivated nowadays in tropical countries for its juicy fruit. The cultivar Kent with green-red epicarp originates from Peru and is currently widespread in the world. Along with Palmer, it constitutes the most widely cultivated introduced cultivars in the Far North region of Cameroon (Bidima, 2016).

Among tropical fruits, the mango is one of those with the greatest economic potential (Calatrava et al., 2013). The increased demand for this fruit in world markets has led to an increase in production in African countries that were not originally mango producers (Ngamo et al., 2010). India ranks as the highest mango-producing country in the world with $13,649,400$ tonnes followed by China $(3,976,716)$ and Indonesia $(2,013,123)$ (Galan, 2004). Mexico is the largest producer in America $(1,855,359)$ and Nigeria with 734,000 tonnes is the leading African mango producer (Galan, 2004). Commercially, the mango is ranked second in the international tropical fruit trade, both in quantity and value (Calatrava et al., 2013). In Cameroon, mango is a seasonal fruit (Bidima, 2016) which constitutes an important source of financial income that improves the living conditions of producers (Eyebe et al., 2014).

Mangifera indica has an andromonoecious floral system (Singh, 1960). The flowers of this plant species are grouped in panicles which bear both perfect, or hermaphroditic, flowers having both pistil and staminate structures and purely male, or staminate, flowers (Singh, 1960). Crop productivity is dependent on both natural and artificial factors (Deuri et al., 2018). Pollination is a vital factor for fruit production in $M$. indica, as it is in so many other fruit crops that rely upon pollination for quantitative and qualitative fruit production (Klein et al., 2007). Yet, very little is known about pollinators and their effects on the yield of $M$. indica in Africa and particularly in Cameroon.

This research work aims to highlight the importance of insect floral visits in the production of mango fruit, given its importance to the Far North region of Cameroon, in economic terms. It also seeks to highlight the importance and reliance of insect pollinators in general in the Far North region in particular. The specific objectives were to 1) compile an inventory of the floral entomofauna associated with the mango tree; 2) study the parameters of the main flower-visiting species we listed; 3) estimate the impact of abundant insect species in fruit production of the mango tree.

\section{Material and Methods}

\section{Study site}

Field experiments took place in Makabaye, a neighbourhood in Maroua, Far North region of Cameroon $\left(10^{\circ} 34.560^{\prime} \mathrm{N} ; 1^{\circ} 17.426^{\prime} \mathrm{E}\right.$; $444 \mathrm{~m}$ a.s.1.). Figure 1 shows the location of the field site. Experiments were conducted during the blooming period of $M$. indica, for two consecutive seasons from October 2018 to February 2019 and from October 2019 until January 2020 respectively. These experiments were carried out inside private mango farms, each of about $2500 \mathrm{~m}^{2}$.
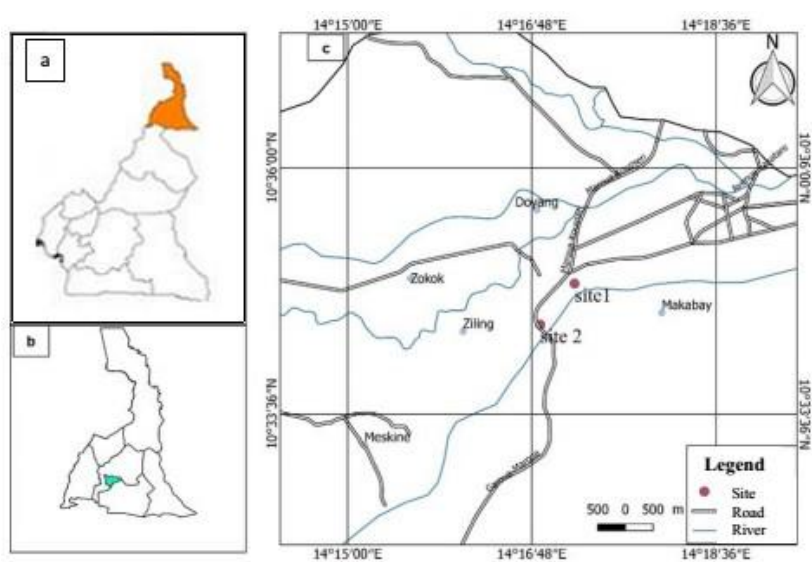

Figure-1. Location of the study site experimental design and data collection protocol

Three bagged and un-bagged panicles per plant were randomly set up on ten mango trees and split into two 
treatments for analysis: treatment A with flowers exposed for pollination as normal and treatment $\mathrm{B}$ with bagged panicles excluding flower activity of pollinators using $50 \times 30 \mathrm{~cm}$. gauze bags.

Observations of insects visiting mango flowers were made on the male and hermaphroditic flowers from treatment A twice a week between 06:00 a.m. and 06:00 p.m. (local time). The number of insect morphospecies visiting these flowers were registered each observation day at three specific time periods: 7:00 - 10:00 a.m., 11:00 a.m. - 2:00 p.m., and 3:006:00 p.m. A transect walk at each selected mango tree was carried out during each time interval, with three observation passes carried out of each flagged panicle within treatment A. During these passes, the numbers of visiting insects were counted, with panicles observed for 6 minutes each time interval. Since some insect visits could have been observed more than once across different panicles, counts were expressed as the number of visits. At least two voucher specimens per anthophilous morphospecies according to their relative abundance were collected using an entomological hand net. Collected specimens were preserved in $90 \%$ ethanol. Subsequently, the insects were sorted into a family, pinned, dried, and kept in entomological boxes which were sent for taxonomic identification.

\section{Insect identification}

Voucher specimens of hoverflies were deposited at the Department of Invertebrates of the Royal Museum for Central Africa (Tervuren, Belgium) for identification. This was done by KJ while blowflies, snout flies, and flesh flies were identified at the Department of Environmental Sciences and Natural Resources, University of Alicante (Spain) by ATC using morphology and various Neotropical identification keys (Rognes and Paterson, 2005; Lutz et al., 2018). All the identified specimens were sent back to us after identification and are now stored at the Laboratory of Entomology (Department of Biological Sciences, Faculty of Science, University of Maroua, Cameroon) where an insect collection is being curated. Other insect species were compared with the reference collection available in the laboratory of entomology of the Institute of Agricultural Research for the Development (IRAD) of Yaoundé in Cameroon.

\section{Foraging parameters of flower-visiting insects}

Several activity parameters of flower-visiting insect species were studied, including; species richness or the number of insect species recorded foraging on the flowers, compositional diversity (using the relative or centesimal abundance of different taxa associated with mango tree flowers), the daily rhythm of activity according to the observation time intervals, frequency of occurrence or frequency of appearance of each insect visitor, duration of individual visits on male and hermaphroditic flowers (using a stopwatch) and foraging speed or number of flowers visited per minute for the most abundant species. Moreover, the visit preference of more abundant insect species was recorded by specifying the floral product harvested (i.e., nectar or pollen) by the insect on the flower visited. Nectar harvesting was coded $\mathrm{Ne}$ and Po was used for pollen collection. Nectar harvesters were observed at the bottom of both type of flowers orienting their mouthparts to the level of the nectary while pollen collectors directly scratched the anthers with their mouthparts. The foraging behaviour of main foragers was also highlighted.

\section{Statistical analysis}

Data analysis were subjected to descriptive statistics using SPSS 20.0 software. The Student's t-test was used for the comparison of means between two values and the $X^{2}$ test was applied for the comparison between two proportions.

The relative abundance $(F)$ was calculated using the following formula: $F(\%)=[(n i / N) \times 100]$ where $F(\%)$ represents the relative abundance of flower visits of species $i$; $n i$ the number of visits by individuals of the species and $N$ the total number of visits by individuals of all species combined.

The frequency of occurrence $(C)$ is the ratio between the number of surveys containing the species considered $(P i)$ and the total number of surveys $(P): C$ $(\%)=[(P i / P) \times 100]$. The $\mathrm{C}$-values obtained enabled to categorize of flower-visiting insects of $M$. indica according to Bigot and Bodot (1973): very accidental species or sporadic species $(C<10 \%)$, accidental species $(10 \% \leq C \leq 24 \%)$; accessory species $(25 \% \leq$ $C \leq 49 \%)$, and constant species $(C \geq 50 \%)$.

For evaluating the influence of flower-visiting insect activity on the fruit set rate of $M$. indica, comparisons were made between tagged clusters from each treatment based on the estimates of the fruit set rate or the ratio actual fruit formed/number of bisexual flowers and the mean rate of mature fruits or the mean of ratio number of mature fruits/number of bisexual flowers per panicle. 


\section{Results}

\section{Compositional diversity of the mango tree} entomofauna

Table 1 shows the different taxa of the floral entomofauna associated with $M$. indica as well as their relative abundance. The arrangement of these taxa made it possible to assess the rank each of them occupies at different levels.

The insect species identified on the flowers of $M$. indica are grouped into 4 orders: Diptera (true flies) (5 families and 12 species), Hymenoptera (bees, wasps, ants) (4 families and 11 species), Coleoptera (beetles) ( 2 families and 2 species), and Lepidoptera (butterflies and moths) represented by a monospecific family.

Table-1. Species richness and relative abundance of the flower-visiting entomofauna associated with Mangifera indica in Makabaye in 2018/2019 and 2019/2020

\begin{tabular}{|c|c|c|c|c|c|c|c|c|}
\hline \multicolumn{3}{|c|}{ Different taxa } & \multicolumn{2}{|c|}{ 2018/2019 } & \multicolumn{2}{|c|}{$2019 / 2020$} & \multicolumn{2}{|c|}{ Total } \\
\hline Orders & Families & Species, & $\mathrm{n}_{1}$ & $F(\%)$ & $\mathbf{n}_{2}$ & $F(\%)$ & $\mathbf{n}_{1}+\mathbf{n}_{2}$ & $\%$ \\
\hline \multirow{16}{*}{ Diptera } & \multirow{4}{*}{ Calliphoridae } & Chrysomya putoria & 1327 & 49.75 & 1477 & 58.91 & 2804 & 54.19 \\
\hline & & Chrysomya albiceps & 103 & 3.86 & 83 & 3.31 & 186 & 3.59 \\
\hline & & Chrysomya chloropyga & 64 & 2.40 & 57 & 2.14 & 121 & 2.34 \\
\hline & & Chrysomya marginalis & 24 & 0.90 & - & - & 24 & 0.46 \\
\hline & \multicolumn{2}{|c|}{ Total Calliphoridae } & 1518 & 56.91 & 1617 & 64.50 & 3135 & 60.59 \\
\hline & \multirow{2}{*}{ Sarcophagidae } & Sarcophaga sp. 1 & 556 & 20.84 & 454 & 18.11 & 1010 & 19.52 \\
\hline & & Sarcophaga sp. 2 & 122 & 4.57 & 36 & 1.43 & 158 & 3.05 \\
\hline & \multicolumn{2}{|c|}{ Total Sarcophagidae } & 678 & 25.42 & 490 & 19.54 & 1168 & 22.57 \\
\hline & \multirow{2}{*}{ Rhiniidae } & Rhyncomya pruinosa & 74 & 2.77 & 82 & 3.27 & 156 & 3.01 \\
\hline & & Rhyncomya soyauxi-forcipata & 13 & 0.48 & 6 & 0.24 & 19 & 0.36 \\
\hline & \multirow{4}{*}{ Syrphidae } & otal Rhiniidae & 87 & 3.26 & 88 & 3.51 & 175 & 3.38 \\
\hline & & Toxomerus floralis & 26 & 0.97 & 31 & 1.23 & 57 & 1.10 \\
\hline & & Mesembrius caffer & 12 & 0.45 & 7 & 0.30 & 19 & 0.36 \\
\hline & & Paragus borbonicus & 8 & 0.30 & - & - & 8 & 0.15 \\
\hline & \multicolumn{2}{|r|}{ Total Syrphidae } & 46 & 1.72 & 38 & 1.51 & 84 & 1.62 \\
\hline & Muscidae & Musca domestica & 38 & 1.42 & 23 & 0.91 & 61 & 1.18 \\
\hline \multicolumn{3}{|c|}{ Total Diptera } & 2367 & 88.75 & 2256 & 89.98 & 4623 & 89.35 \\
\hline \multirow{14}{*}{ Hymenoptera } & \multirow{5}{*}{ Apidae } & Apis mellifera & 57 & 2.14 & 13 & 0.52 & 70 & 1.35 \\
\hline & & Xylocopa olivacea & 31 & 1.16 & 27 & 1.07 & 58 & 1.12 \\
\hline & & Xylocopa inconstans & 23 & 0.86 & 34 & 1.35 & 57 & 1.10 \\
\hline & & Xylocopa torrida & 11 & 0.41 & 3 & 0.12 & 14 & 0.27 \\
\hline & & Dactylurina staudingeri & 7 & 0.26 & - & - & 7 & 0.13 \\
\hline & \multicolumn{2}{|r|}{ Total Apidae } & 129 & 4.84 & 77 & 3.07 & 206 & 3.98 \\
\hline & \multirow{3}{*}{ Formicidae } & Camponotus brutus & 33 & 1.23 & 61 & 2.43 & 94 & 1.82 \\
\hline & & Pheidole megacephala & 17 & 0.64 & 21 & 0.84 & 38 & 0.73 \\
\hline & & Myrmicaria sp. & 6 & 0.22 & - & - & 6 & 0.12 \\
\hline & \multicolumn{2}{|c|}{ Total Formicidae } & 56 & 2.10 & 82 & 3.27 & 138 & 2.66 \\
\hline & \multirow{2}{*}{ Vespidae } & Belonogaster juncea & 28 & 1.05 & 11 & 0.44 & 39 & 0.75 \\
\hline & & Polistes canadensis & 21 & 0.79 & 33 & 1.31 & 54 & 1.04 \\
\hline & \multicolumn{2}{|r|}{ Total Vespidae } & 49 & 1.83 & 44 & 1.75 & 93 & 1.80 \\
\hline & Megachilidae & Anthidium sp. & 3 & 0.11 & - & - & 3 & 0.06 \\
\hline \multicolumn{3}{|c|}{ Total Hymenoptera } & 237 & 8.88 & 203 & 8.09 & 440 & 8.50 \\
\hline \multirow{2}{*}{ Coleoptera } & Coccinellidae & Coccinella septempunctata & 34 & 1.27 & 19 & 0.76 & 53 & 1.02 \\
\hline & Scarabaeidae & Pelidnoda sp. & 17 & 0.64 & 23 & 0.91 & 40 & 0.77 \\
\hline \multicolumn{3}{|c|}{ Total Coleoptera } & 51 & 1.91 & 42 & 1.67 & 93 & 1.79 \\
\hline Lepidoptera & Acraeidae & Acraea acerata & 12 & 0.45 & 6 & 0.24 & 18 & 0.35 \\
\hline 4 Orders & 12 Families & 26 Species & 2667 & 100 & 2507 & 100 & 5174 & 100 \\
\hline
\end{tabular}

$\mathrm{n}_{1}=$ visits by individuals in 2018/2019; $\mathrm{n}_{2}=$ visits by individuals in $2019 / 2020 ; F(\%)=$ Relative abundance. 
Among these orders, Diptera was predominant with a relative abundance of $88.75 \%$ in 2018/2019 and $89.98 \%$ in $2019 / 2020$. The other three orders accounted for $11.25 \%$ and are thus classified: Hymenoptera (8.88\% in $2018 / 2019$ and $8.09 \%$ in $2019 / 2020$ ), Coleoptera $(1.91 \%$ in $2018 / 2019$ and $1.67 \%$ in $2019 / 2020)$, and Lepidoptera $(0.45 \%$ in $2018 / 2019$ and $0.24 \%$ in $2019 / 2020$ ). In both seasons, the differences are not significant between the relative abundance values within the same order $(p>0.05)$; this is an illustration of the stability of the floral entomofauna associated with $M$. indica at the order level from year to year.

The different species of insects listed on the flowers of the mango tree are grouped into 12 families. In decreasing order of their relative abundance are Calliphoridae $(49.75 \%$ in $2018 / 2019$ and $58.91 \%$ in 2019/2020), Sarcophagidae (25.42\% in 2018/2019 and $19.54 \%$ in $2019 / 2020$ ), Apidae (4.84\% in $2018 / 2019$ and $3.07 \%$ in $2019 / 2020)$, Rhiniidae $(2.77 \%$ in $2018 / 2019$ and 3.27 in 2019/2020), Formicidae (2.10\% in $2018 / 2019$ and $3.27 \%$ in $2019 / 2020$ ), Vespidae $(1.83 \%$ in $2018 / 2019$ and $1.75 \%$ in $2019 / 2020)$, Syrphidae $(1.72 \%$ in $2018 / 2019$ and $1.51 \%$ in 2019/2020), Muscidae (1.42\% in 2018/2019 and 0.91\% in 2019/2020), Coccinellidae (1.27\% in 2018/2019 and $0.76 \%$ in $2019 / 2020)$, Scarabeidae $(0.64 \%$ in $2018 / 2019$ and $0.91 \%$ in $2019 / 2020$ ), Acraeidae (0.45\% in $2018 / 2019$ and $0.24 \%$ in $2019 / 2020)$, and Megachilidae $(0.11 \%$ in $2018 / 2019$ and $0 \%$ in 2019/2020).

The flower visiting entomofauna of $M$. indica was diverse with 26 species observed during the two cumulative experimental seasons with in particular 2667 visits of 26 species in 2018/2019 and 2507 visits of 21 species in 2019/2020. According to their increasing relative abundance, the various listed insect species are classified as follows: Anthidium sp. (0.11\% in 2018/2019 and 0\% in 2019/2020), Myrmicaria sp. (0.22\% in 2018/2019, 0\% in 2019/2020), Dactylurina staudingeri (0.26\% in 2018/2019, $0 \%$ in 2019/2020), Paragus borbonicus (0.30\% in 2018/2019, 0\% in 2019/2020), Xylocopa torrida (0.41\% in 2018/2019, $0.12 \%$ in $2019 / 2020)$, Acraea acerata $(0.45 \%$ in $2018 / 2019,0.24 \%$ in 2019/2020), Rhyncomya soyauxiforcipata (0.48\% in 2018/2019, $0.24 \%$ in 2019/2020), Mesembrius caffer $(0.45 \%$ in $2018 / 2019,0.30 \%$ in 2019/2020), Chrysomya marginalis $(0.90 \%$ in 2018/2019, 0\% in 2019/2020), Pheidole megacephala $(0.64 \%$ in $2018 / 2019,0.84 \%$ in $2019 / 2020)$,
Belonogaster juncea $(1.05 \%$ in $2018 / 2019,0.44 \%$ in 2019/2020), Pelidnota sp. (0.64\% in 2018/2019, 0.91\% in $2019 / 2020)$, Coccinella septempunctata $(1.27 \%$ in 2018/2019, 0.76\% in 2019/2020), Polistes canadensis (0.79\% in $2018 / 2019,1.31 \%$ in $2019 / 2020)$, Xylocopa inconstans (0.86\% in 2018/2019, $1.35 \%$ in $2019 / 2020$ ), Toxomerus floralis $(0.97 \%$ in $2018 / 2019,1.23 \%$ in 2019/2020), Xylocopa olivacea (1.16\% in 2018/2019, $1.07 \%$ in 2019/2020), Musca domestica (1.42\% in 2018/2019, $0.91 \%$ in 2019/2020), Apis mellifera $(2.14 \%$ in $2018 / 2019,0.52 \%$ in 2019/2020), Camponotus brutus (1.23\% in 2018/2019, $2.43 \%$ in 2019/2020), Chrysomya chloropyga $(2.40 \%$ in 2018/2019, 2.14\% in 2019/2020), Rhyncomya pruinosa $(2.77 \%$ in $2018 / 2019, \quad 3.27 \%$ in $2019 / 2020)$, Sarcophaga sp. 2 (4.57\% in $2018 / 2019,1.43 \%$ in 2019/2020), Chrysomya albiceps (3.86\% in 2018/2019, $3.31 \%$ in 2019/2020), Sarcophaga sp. 1 (20.84\% in 2018/2019, 18.11\% in 2019/2020), and Chrysomya putoria $(49.75 \%$ in $2018 / 2019,58.91 \%$ in $2019 / 2020)$. Overall, $M$. indica is an essentially attractive plant species to flies which, due to their relative abundance, are thought to play a major role in the pollination of mango flowers.

\section{Frequency of occurrence}

Table 2 gives the frequency of occurrence $C$ of the flower-visiting insect species recorded foraging on $M$. indica flowers.

Following Bigot and Bodot (1973) insect species were classified into four groups: 1) constant species: $C$. putoria and Sarcophaga sp. 1;2) accessory species: $C$. albiceps, C. chloropyga, C. brutus, R. pruinosa, $M$. domestica, X. olivacea, T. floralis, $M$. caffer, $C$. septempunctata, and Sarcophaga sp. 2; 3) accidental species: A. mellifera, Pelidnota sp., C. marginalis, A. acerata, $R$. soyauxi-forcipata, $P$. megacephala, $P$. borbonicus, and $X$. torrida; 4) sporadic species: Myrmicaria sp., $B$. juncea, $X$. inconstans, $P$. canadensis, Anthidium sp. In all, the category of a given insect species did not change over the two years of study.

\section{Daily rhythm of insect activity}

Figure 2 shows the distribution of insect visits on the flowers of $M$. indica according to the observation time frames. In both years, flower-visiting insects of $M$. indica were observed throughout the day. Foraging activity was high in the morning (7:00-10:00 a.m.), decreased at midday (11:00 a.m.- 2:00 p.m.) and 
increased again in the evening (3:00-6:00 p.m.). The daily rhythm of insect activity was highly correlated with the group of constant species, namely $C$. putoria (Calliphoridae) and Sarcophaga sp. (Sarcophagidae) in $2018 / 2019(r=0.99 ; d f=2 ; p<0.05)$ and in $2019 / 2020$ $(r=0.99 ; d f=2 ; p<0.05)$.

Table-2. Frequency of occurrence $C_{1}$ and $C_{2}$ for each of the flower visiting insect of Mangifera indica and the different categories according to Bigot and Bodot (1973).

\begin{tabular}{|c|c|c|c|c|c|}
\hline & \multicolumn{2}{|c|}{$2018 / 2019$} & \multicolumn{2}{|c|}{$2019 / 2020$} & \multirow[b]{2}{*}{ Insect categories } \\
\hline Species & $P_{1}$ & $C_{1}(\%)$ & $P_{2}$ & $C_{2}(\%)$ & \\
\hline Chrysomya putoria & 28 & 87.50 & 20 & 100.00 & \multirow{2}{*}{$\begin{array}{l}\text { Constant species } \\
\quad(C \geq 50 \%)\end{array}$} \\
\hline Sarcophaga sp. 1 & 21 & 65.63 & 18 & 90.00 & \\
\hline Chrysomya albiceps & 15 & 46.88 & 9 & 45.00 & \multirow{10}{*}{$\begin{array}{c}\text { Accessory species } \\
(25 \% \leq \mathrm{C} \leq 49)\end{array}$} \\
\hline Sarcophaga sp. 2 & 15 & 46.88 & 9 & 45.00 & \\
\hline Chrysomya chloropyga & 13 & 40.63 & 9 & 45.00 & \\
\hline Camponotus brutus & 11 & 34.37 & 9 & 45.00 & \\
\hline Musca domestica & 11 & 34.37 & 9 & 45.00 & \\
\hline Xylocopa olivacea & 9 & 28.13 & 8 & 40.00 & \\
\hline Toxomerus floralis & 9 & 28.13 & 7 & 35.00 & \\
\hline Rhyncomya pruinosa & 9 & 28.13 & 8 & 40.00 & \\
\hline Mesembrius caffer & 9 & 28.13 & 7 & 35.00 & \\
\hline $\begin{array}{l}\text { Coccinella } \\
\text { septempunctata }\end{array}$ & 9 & 28.13 & 6 & 30.00 & \\
\hline Apis mellifera & 3 & 18.75 & 2 & 10.00 & \multirow{9}{*}{$\begin{array}{c}\text { Accidental species } \\
(10 \% \leq \mathrm{C} \leq 24 \%)\end{array}$} \\
\hline Pelidnota sp. & 3 & 18.75 & 4 & 20.00 & \\
\hline Chrysomya marginalis & 3 & 18.75 & - & - & \\
\hline Acraea acerata & 3 & 15.63 & 2 & 10.00 & \\
\hline $\begin{array}{l}\text { Rhyncomya soyauxi- } \\
\text { forcipata }\end{array}$ & 5 & 15.63 & 3 & 15.00 & \\
\hline Pheidole megacephala & 5 & 15.63 & 2 & 10.00 & \\
\hline Paragus borbonicus & 5 & 15.63 & - & - & \\
\hline Xylocopa torrida & 3 & 12.50 & 3 & 15.00 & \\
\hline $\begin{array}{l}\text { Dactylurina } \\
\text { staudingeri }\end{array}$ & 4 & 12.50 & - & - & \\
\hline Myrmicaria sp. & 3 & 9.38 & - & - & \multirow{5}{*}{$\begin{array}{l}\text { Sporadic species } \\
\quad(C<10 \%)\end{array}$} \\
\hline Belenogaster juncea & 2 & 6.25 & 1 & 5.00 & \\
\hline Xylocopa inconstans & 2 & 6.25 & 1 & 5.00 & \\
\hline Polistes canadensis & 2 & 6.25 & 1 & .00 & \\
\hline Anthidium sp. & 2 & 6.25 & - & - & \\
\hline
\end{tabular}

Legend: $C=\left[\left(P_{i} / P\right)\right.$ x 100] $=$ Frequency of occurrence $P_{i}=$ Number of samples containing a given insect species; $P=30$ in $2018 / 2019$ and 20 in $2019 / 2020=$ Total number of samples

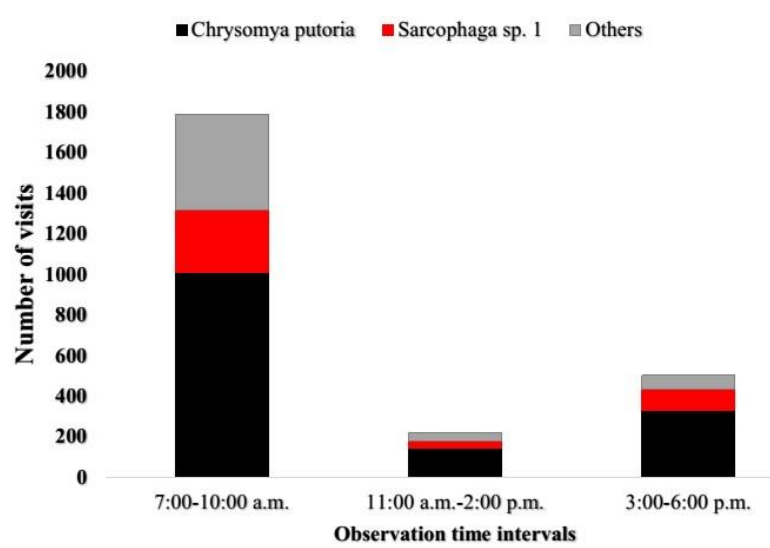

Figure-2. Cumulative values of the variation of insect visits as a function of daily time intervals

\section{Floral products harvested}

Figure 3 is an illustration of the repartition of floral products (nectar and pollen) harvested by constant species. Of over 200 observations of $C$. putoria visits, $88 \%$ (in 2018/2019) and 92\% (in 2019/2020) were for nectar harvesting and only $12 \%$ and $8 \%$ for pollen collection during both years respectively. The difference between these proportions was significant in $2018 / 2019\left(X^{2}=186.04 ; d f=1 ; p<0.05\right)$ and in $2019 / 2020\left(X^{2}=190.04 ; d f=1 ; p<0.05\right)$. Of over 200 observations of Sarcophaga sp. 1 visits, 92\% (in 20182019) and 97\% (in 2019/2020) were found to be nectar foraging visits, while only $8 \%$ and $3 \%$ were for pollen harvesting. The difference between both proportions was significant in 2018/2019 $\left(X^{2}=190.13\right.$; $d f=1 ; p<0.05)$ and in $2019 / 2020\left(X^{2}=200.05 ; d f=1\right.$; $p<0.05)$. Based upon our evidence $C$. putoria and Sarcophaga sp. 1 can be said to be highly nectarophagous on the flowers of mango trees in Maroua.

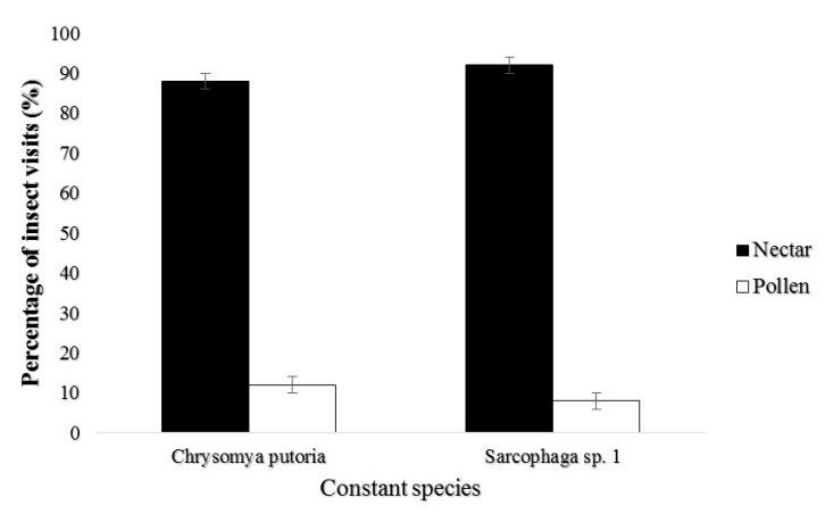

Figure-3. Cumulative value on the variation in floral products harvested 


\section{Duration of visit}

As direct pollen collection was scarce, the duration of visits was measured only for nectar harvesting (table 3).

Table-3. Mean duration of an insect visit as a function of floral sex and years

\begin{tabular}{|c|c|c|c|c|}
\hline & \multicolumn{3}{|c|}{ Mean duration of the visit (sec) } \\
\hline Insect species & \multirow{2}{*}{$\begin{array}{c}\text { Floral } \\
\text { sex }\end{array}$} & $\mathbf{2 0 1 8 / 2 0 1 9}$ & $\mathbf{2 0 1 9 / 2 0 2 0}$ \\
\hline $\begin{array}{c}\text { Chrysomya } \\
\text { putoria }\end{array}$ & \multirow{2}{*}{30} & Male & $\begin{array}{c}7.38 \pm \\
2.03 \mathrm{a}\end{array}$ & $\begin{array}{c}6.79 \pm \\
1.73 \mathrm{a}\end{array}$ \\
\hline \multirow{2}{*}{30} & \multirow{2}{*}{ Bisexual } & $\begin{array}{c}11.97 \pm \\
4.17 \mathrm{~b}\end{array}$ & $\begin{array}{c}13.01 \pm \\
3.58 \mathrm{~b}\end{array}$ \\
\hline \multirow{2}{*}{ Sarcophaga sp. 1 } & \multirow{2}{*}{30} & \multirow{2}{*}{ Male } & $\begin{array}{c}5.67 \pm \\
3.22 \mathrm{a}\end{array}$ & $\begin{array}{c}5.81 \pm \\
2.42 \mathrm{a}\end{array}$ \\
\hline & \multirow{2}{*}{30} & \multirow{2}{*}{ Bisexual } & $\begin{array}{c}7.89 \pm \\
3.21 \mathrm{~b}\end{array}$ & $\begin{array}{c}8.21 \pm \\
2.92 \mathrm{~b}\end{array}$ \\
\hline
\end{tabular}

Mean values in the same column (mean duration of a given insect species as a function of the floral sex) with different letters vary significantly $(P<0.05)$

For $C$. putoria, the average duration of nectar collection on a male flower was $7.38 \pm 2.03 \mathrm{sec}$ in $2018 / 2019$ and $6.79 \pm 1.73 \mathrm{sec}$ in $2019 / 2020$; the difference between these two means was not significant $(t=1.28 ; d f=58$; $p>0.05)$. On hermaphrodite flowers, the corresponding values were: $11.97 \pm 4.17 \mathrm{sec}$ and 13.01 $\pm 3.58 \mathrm{sec}$; the difference between these values was also not significant $(t=1.79 ; d f=58 ; p>0.05)$. The difference between the average duration of visits was however significant between male flowers and hermaphrodite flowers in $2018(t=8.57 ; d f=58 ; p<$ $0.05)$ and in $2019(t=11.08 ; d f=58 ; p<0.05)$.

For Sarcophaga sp. 1, the average duration of a nectar collection visit on a male flower was $5.67 \pm 3.22 \mathrm{sec}$ in $2018 / 2019$ and $5.81 \pm 2.42 \mathrm{sec}$ in $2019 / 2020$; the difference between these two means was not significant $(t=0.71 ; d f=58 ; p>0.05)$. On a hermaphrodite flower, the corresponding values were: $7.89 \pm 3.21 \mathrm{sec}$ and $8.21 \pm 2.92 \mathrm{sec}$; the difference between these values was also not significant $(t=1.67 ; d f=58 ; p>0.05$ ). The difference between the average visits and the average duration of visits on a male flower and a hermaphrodite flower was significant in $2018(t=5.13$; $d f=58 ; p<0.05)$ and in $2019(t=7.28 ; d f=58 ; p<$ $0.05)$.

Overall, the mean duration of a floral visit varied from year to year, and for the same year from insect to insect, depending on whether the type of flower visited was male or hermaphrodite.

\section{Foraging speed}

The values of the mean foraging speed, as well as the mean duration of a visit, were exclusively recorded for C. putoria and Sarcophaga sp. 1 given their high relative abundance compared to the other insects listed. Table 4 shows the average values of foraging speed in $2018 / 2019$ as well as in 2019/2020. This was $4.18 \pm$ 1.27 flowers/minute $(\mathrm{n}=30)$ in C. putoria and $2.63 \pm$ 1.07 flowers/minute $(\mathrm{n}=20)$ in Sarcophaga sp. 1 in 2018/2019. The difference between these two means was significant $(t=4.67 ; d f=49 ; p<0.05)$. The corresponding values in 2019/2020 were respectively $4.31 \pm 1.43$ flowers/minute $(\mathrm{n}=30)$ and $2.57 \pm 1.38$ flowers/minute $(\mathrm{n}=20)$ for $t=5.14 ; d f=49 ; p<0.05$. The significant differences obtained here assume that C. putoria visited more flowers per unit time than Sarcophaga sp. 1. Furthermore, the difference in the average value of the foraging speed for each insect species was not significant over the two years of the experiment.

Table-4. Mean values of the foraging speed as a function of years and constant insect species

\begin{tabular}{|c|c|c|c|}
\hline & \multicolumn{3}{|c|}{ Mean foraging speed (flower/min) } \\
\hline Insects & $\boldsymbol{n}$ & $\mathbf{2 0 1 8 / 2 0 1 9}$ & $\mathbf{2 0 1 9 / 2 0 2 0}$ \\
\hline Chrysomya putoria & 30 & $4.18 \pm 1.27 \mathrm{a}$ & $4.31 \pm 1.43 \mathrm{a}$ \\
\hline Sarcophaga sp. 1 & 20 & $2.63 \pm 1.07 \mathrm{~b}$ & $2.57 \pm 1.38 \mathrm{~b}$ \\
\hline
\end{tabular}

Mean values in the same column with different letters vary significantly $(P<0.05)$

\section{Foraging behavior of anthophilous insects of Mangifera indica}

During their foraging activity on the flowers of $M$. indica, C. putoria and Sarcophaga sp. 1 showed almost similar foraging behavior. Indeed, taking into account the small size of the flowers of the host plant, these flies were permanently in contact with the reproductive organs of the male and hermaphrodite flowers. Although more attached to collecting nectar than pollen, in either case, contact with the anthers on both types of flowers and the stigma on the hermaphroditic flowers was found to be constant. During their floral activity, individuals visited the flowers of one panicle one after the other. In addition, insect transitions were also noted from the flower of a given panicle to a neighboring one. It is therefore very likely that these insects, during their nectar foraging trips, promoted pollination of mango flowers by transferring pollen 
grains on the stigma as they moved from panicle to panicle.

\section{Impact of insect activities on fruit production of the mango tree}

The results reported in table 5 below indicate the influence of insect flower visits on the evolution of fruit yields of $M$. indica in Makabaye. From this table, the following main results emerge: all hermaphrodite flowers did not form fruit reaching maturity; the average fruiting rate varied from $37.53 \%$ in treatment B to $53.24 \%$ in treatment $A$ in $2018 / 2019$ and from $39.10 \%$ to $67.25 \%$ in $2019 / 2020$. The difference in these values is significant between the two treatments in $2018 / 2019\left(X^{2}=7.54 ; d f=1 ; p<0.05\right)$ and in $2019 / 2020\left(X^{2}=16.83 ; d f=1 ; p<0.05\right)$; no fruit from hermaphrodite flowers within treatment $\mathrm{B}$ reached physiological maturity in either 2018/2019 and 2019/2020; only open pollination (treatment A) allowed the production of edible fruits, indicating the important role played by $C$. putoria and Sarcophaga sp. 1 the most abundant and frequent species in the pollination and production of the mango tree in Maroua. Several young mangoes that formed within treatment B were dropped one month after the fruit started to set but 3 to 9 fruits reached physiological maturity per panicle in treatment A yearly, i.e. an average rate of mature fruits of $1.07 \%$ in $2018 / 2019$ and $1.85 \%$ in $2019 / 2020$. Overall, the mango tree depends for its fruit production on floral visits from anthophilous insects, among which the Diptera play a major role.

Table-5. Fruit set on Mangifera indica cv. Kent from treatments $A$ and $B$

\begin{tabular}{|c|c|c|c|c|c|c|c|}
\hline Seasons & $\begin{array}{c}\text { Treatme } \\
\text { nts }\end{array}$ & $\mathbf{n}$ & $\boldsymbol{q}^{\mathbf{*}}$ & $\mathbf{F}$ & $\begin{array}{c}\mathbf{F 1} \\
(\boldsymbol{\%})\end{array}$ & $\mathbf{F m}$ & $\mathbf{M}(\boldsymbol{\%})$ \\
\hline \multirow{2}{*}{$\begin{array}{c}2018 / 20 \\
19\end{array}$} & $\mathrm{~A}$ & 30 & $\begin{array}{c}432 \pm \\
107\end{array}$ & $\begin{array}{c}230 \pm \\
11\end{array}$ & 53.24 & $\begin{array}{c}4.63 \pm \\
1.96\end{array}$ & $\begin{array}{c}1.07 \pm \\
0.53\end{array}$ \\
\cline { 2 - 8 } & $\mathrm{B}$ & 30 & $\begin{array}{c}397 \pm \\
94\end{array}$ & $\begin{array}{c}149 \pm \\
75\end{array}$ & 37.53 & 0.00 & 0.00 \\
\cline { 2 - 8 } & $\mathrm{A}$ & 30 & $\begin{array}{c}406 \pm \\
89\end{array}$ & $\begin{array}{c}273 \pm \\
89\end{array}$ & 67.25 & $\begin{array}{c}7.51 \pm \\
1.67\end{array}$ & $\begin{array}{c}1.85 \pm \\
0.89\end{array}$ \\
\hline $\begin{array}{c}2019 / 20 \\
20\end{array}$ & $\mathrm{~B}$ & 30 & $\begin{array}{c}289 \pm \\
78\end{array}$ & $\begin{array}{c}113 \pm \\
74\end{array}$ & 39.10 & 0.00 & 0.00 \\
\hline
\end{tabular}

Legend: $n=$ Number of panicles; $q^{x}=$ hermaphrodite flowers; $F=$ Number of young fruits formed; F1 = fruiting rate; $\mathrm{Fm}=$ mean number of mature fruits/panicle; $\mathrm{M}(\%)=$ mean ratio of mature fruit per panicle.

\section{Discussion}

A large number of insect species belonging to the orders Diptera, Hymenoptera, Coleoptera and Lepidoptera have already been reported on mango tree flowers in India (Spencer and Kennard, 1955), Australia (Anderson et al., 1982), Costa Rica (Free and Williams, 1976), Florida (Free and Williams, 1976), Jamaica (Galan et al., 1997), and the Canary Islands (Jiron and Hedström, 1985). The above-mentioned insect orders are the same as we had listed active on $M$. indica flowers in Maroua.

The results also reveal the upsurge of flies as the main flower-visiting insects of the mango tree in our experimental site. Among these flies, the main active species belong to the families Calliphoridae (Chrysomya putoria) and Sarcophagidae (Sarcophaga sp. 1) although we recorded 26 insect species visiting $M$. indica flowers. Our results are in agreement with those of several other authors who indicated flies as the main pollinators of mango trees throughout the world. In Israel, Dag and Gazit (2000) revealed two Calliphoridae (Chrysomya albiceps and Lucilia sericata) and the house fly Musca domestica as the main pollinating insects of $M$. indica; in Isräel, Costa Rica, India, the Philippines, Brazil, Colombia, several species of Blowflies have been noted as major visitors in the mango tree flower entomofauna (Corredor and García, 2011; Kumar et al., 2012).

Another important aspect that emerges from this study is the virtual absence of the honey bee in the floral entomofauna of $M$. indica despite the presence in the experimental site of a colony of this species. This work is therefore a perfect illustration that $A$. mellifera can discriminate certain plant species in their direct environment. This would be linked to the notion of preference that characterizes this bee species. Indeed, it is known in the literature that $M$. indica produces pollen and nectar in very small quantities (Singh, 1960). The honey bee, being a thrifty species, would prefer to forage on other plant species so that the work-energy associated with movement is not greater than that devoted to foraging (Ségeren et al., 1996). Nevertheless, some other work has shown that social bees are the main pollinators of the mango tree. This is particularly the case with Apis mellifera in South Africa (Carvalheiro et al., 2010) and in Japan (Sasaki et al., 1998), Apis dorsata, A. florea, and A. cerena in India (Siqueira et al., 2008) and in Taiwan (Sung et al., 2006). From the above, the floral entomofauna can vary from one plant species to another and for the same plant 
species, from one agro-ecological region to another (Klein et al., 2007). Moreover, a particular pollinating insect may be predominant on a particular plant in a given agro-ecological zone; while in another agroecological zone, this same insect may be absent or play a less important role in the pollination of the same plant species (Mesler et al., 1980).

Regarding fruit yield of $M$. indica, our results revealed the low involvement of self-pollination in mango production. Indeed, the hermaphrodite flowers are selfpollinated but the incompatibility of some pollen and stigmas cause failure in mango fruit set (Huda et al., 2015). This is why in caged treatments, almost all of the fruit aborts and drops, and even though these fruits are formed, none of them reach maturity (Singh et al., 2005). In some Indian mango tree cultivars such as Dashehari, Langra, Chausa and Bombay Green, fruit set after self-pollination gives negligible results in the range of $0.0-1.68 \%$ (Sharma and Singh, 1970). The rates of formation of mature fruits from self-pollination have already been obtained for cultivars 'Amrapali' $(0.37 \%)$ and ika Mallika (0\%) (Dutta et al., 2013). According to the observations of Gehrke-Vélez et al. (2012), self-pollination in the mango tree is at the origin of the morphological deterioration of the fruits and therefore of the substantial reduction in production. This is because self-pollinated stigmas result in the formation of embryos, but self-incompatibility follows in the early stages of embryonic development. This has resulted in abortion of immature fruits and, in advanced cases, abnormal development of fruits called "nubbins" (Gehrke-Vélez et al., 2012). Young fruit drop of the self-pollinated variety 'Amrapali' has been reported to be significant during the first 18 days of development, and about $99 \%$ of self-pollinated hermaphrodite flowers drop during this period (Dutta et al., 2013).

On the other hand, treatment $\mathrm{A}$ in which the flowers were exposed to the pollination activity of the associated floral entomofauna mainly flies formed fruits which result in physiological and therefore physical maturity. The important role of insect pollinators in mango production has been recognized in many mango-producing countries in the world (Huda et al., 2015). Usman et al. (2001) found that cross pollination had contributed largely to the increase of mango fruit set, hence external agents are necessary to transfer the pollen of mango flowers and assume fruit set and maturity. In the case of this study, two true fly species namely $C$. putoria and Sarcophaga sp. 1 were more abundant and active on the flowers of the host plant $M$. indica. However, it is also to be noted a large percentage of fall of young fruits during the setting in treatment A. This drop of young fruits is a specific characteristic of reproduction and development in fruit plants which imposes abscission on a large number of fruits (Mc Collum et al., 1987). According to Brown and Mc Neil (2006), the development of the last fruits formed on a tree is limited, not only by the lack of resources, but also by evolutionary genetic strategies; including a selective abortion strategy at the expense of higher fruits.

\section{Conclusion}

This work deals with the importance of flies on pollination and fruit set in $M$. indica plantation in Maroua, Cameroon. The lack of insect pollinators is detrimental to fruit set in the variety Kent studied. Indeed, the fertilization resulting from self-pollination induced the drop of the young fruits because of selfincompatibility. However, the effective fruit production of $M$. indica depends on the combination action of flower-visiting insects, $C$. putoria and Sarcophaga sp. 1 being the main pollen vectors.

\section{Acknowledgement}

Authors are thankful to KJ (Department of invertebrates, Royal Museum for Central Africa) and ATC (department of Environmental Sciences and Natural Resources, University of Alicante, Spain) for their contribution for identifying fly species collected from field experiment. The contribution of PB for proofreading the manuscript is hereby acknowledged.

\section{Disclaimer: None. \\ Conflict of Interest: None. Source of Funding: None.}

\section{References}

Anderson DL, Sedgley M, Short JRT and Allwood AJ, 1982. Insect pollination of mango in northern Australia. Aust. J. Agric. Res. 33: 541-548.

Bidima IM, 2016. Cameroun: Mangues, la production débute dans le Littoral et s'achève à l'Ouest. La Voix du Paysan, Yaoundé, Cameroon.

Bigot L and Bodot P, 1973. Contribution à l'étude biocénotique de la garrigue à Quecus coccifera Composition biotique du peuplement des Invertébrés. Vie \& Milieu. 23: 229-249. 
Breeze TD, Bailey AP, Balcombe KG and Potts SG, 2011. Pollination services in the UK: How important are honeybees? Agric. Ecosyst. Environ. 142: 3-4.

Brown AO and Mc Neil JN, 2006. Fruit production in cranberry (Ericaceae: Vaccinium macrocarpon): A bet-hedging strategy to optimize reproductive effort. Am. J. Bot. 93(6): 910-916.

Calatrava RJ, Gonzalez Roa MC and Sayadi S, 2013. Intra-European mango trade business: facts from figures. Acta Hortic. https://doi.org/10.17660/ActaHortic.2013.992.3.

Carvalheiro LG, Seymour CL, Veldtman R and Nicolson SW, 2010. Pollination services decline with distance from natural habitat even in biodiversity-rich areas. J. Appl. Ecol. 47: 810-820.

Corredor JP and García J, 2011. Fenología reproductiva, biología floral y visitantes florales en los cultivares de mango (Mangifera indica L.) Hilacha y Tommy Atkins en el valle del alto Magdalena (Colombia). Review Corpoica. 12: 21-32.

Dag A and Gazit S, 2000. Mango pollinators in Israel. J. Appl. Hort. 2: 39-43.

Deuri A, Rahman A, Gogoi J, Borah P and Mathari M, 2018. Pollinator diversity and effect of Apis cerana F. pollination on yield of mango (Mangifera indica L.). J. Entomol. Zool. Stud. 6(5): 957-961.

Dutta SK, Srivastav M, Rymbai H, Chaudhary R, Singh AK, Dubey AK and Lal K, 2013. Pollen-pistil interaction studies in mango (Mangifera indica L.) cultivars. Sci. Hortic. 160: 213-221.

Eyebe JP, Awono A, Ingram V and Shure J, 2014. Mangues sauvages au Cameroun. Technical report, CIFORD (Eds.), France.

Fontaine C, Dajoz I, Meriguet J and Loreau M, 2006. Functional Diversity of Plant-Pollinator Interaction Webs Enhance the Persistence of Plant Communities. Biol. 4: 0129-0135.

Free JB and Williams IH, 1976. Insect pollination of Anacardium occideniale L., Mangifera indica L., Blighia sapida Koenig and Persea americana Mill. Trop. Agric. 53: 125-139.

Galan SV, 2004. Mango production and world market: current situation and future prospects. Acta Hortic. 645: 107-116.

Galan SV, Fernandez Galvan D, Hernandez Conde JC and Morales Navkrro A, 1997. Preliminary studies on fruit-set of mango cultivar Tommy Atkins under greenhouse cultivation in the Canary Islands. Acta Hortic. 455: 530-537.

Gehrke-Vélez M, Castillo-Vera A, Ruiz-Bello C,
Moreno-Martinez JL and Moreno-Basurto G, 2012. Delayed self-incompatibility causes morphological alterations and crop reduction in 'Ataúlfo' mango (Mangifera indica L.). New Zeal. J. Crop Hortic. 40: 215-227.

Hodgkiss D, Brown MJF and Fountain MT, 2018. Syrphinae hoverflies are effective pollinators of commercial strawberry. J. Pollinat. Ecol. 22(6): 55-66.

Huda AN, Che Salmah MR, Abu Hassan A, Hamdan A and Abdul Razak MN, 2015. Pollination services of Mango flower pollinators. J. Insect Sci. 15 (1): 113-120.

Jiron LF and Hedström I, 1985. Pollination ecology of mango (Mangifera indica L.) (Anacardiaceae) in the Neotropic region. Turrialba. 35: 269-277.

Klein AM, Vaissière BE, Cane J, Steffan-Dewenter I, Cunningham S, Kremen C and Tscharntke T, 2007. Importance of pollinators in changing landscape for world crop. P. Roy. Soc. B: Biol. Sci. 274: 3033013.

Kumar P, Baskaran S, Sundaravadivelan C, Kuberan T and Anburaj J, 2012. Influence of environmental factors on insect pollination activity of Mangifera indica Linn. Asian J. Plant Sci. Res. 2: 692-698.

Larson BMH, Keven PG and Inouye DW, 2001. Flies and flowers: taxonomic diversity of anthophiles and pollinators. Canad. Entomol. 133: 439-465.

Lutz L, Williams KA, Villet MH, Ekanem $\mathrm{M}$ and Szpila K, 2018. Species identification of adult African blowflies (Diptera: Calliphoridae) of forensic importance. Int. J. Legal Med. 132 (3): 831-842.

Mc Collum TG, Cantlife J and Paris HS, 1987. Flowering, fruit set and fruit development in bird nest-type muskmelons. J. Am. Soc. Hortic. Sci. 112: 161-164.

Mesler MR, Ackerman JD and Lu KL, 1980. The effectiveness of fungus gnats as pollinators. Am. J. Bot. 67: 564-567.

Ngamo TL, Ladang D, Vayssières JF and Lyannaz JP, 2010. Diversité des espèces de mouches des fruits (Diptera : Tephritidae) dans un verger mixte dans la localité de Malang (Ngaoundéré, Cameroun). Int. J. Biol. Chem. Sci. 4(5): 1425-1434.

Rader R, Howlett, BG, Cunningham SA, Westcott DA, Newstrom-Lloyd LE, Walker MK, Teulon DAJ and Edwards W, 2009. Alternative pollinator taxa are equally efficient but not as effective as the honeybee in a mass flowering crop. J. Appl. Ecol. 46: 1080-1087. 
Rognes K and Paterson HEH, 2005. Chrysomya chloropyga (Wiedemann, 1818) and C. putoria (Wiedemann, 1830) (Diptera: Calliphoridae) are two different species. Afr. Entomol. 13 (1): 49-70.

Sasaki K, Takebayashi T and Utsunomiya N, 1998. Fruit set and fruit growth of 'Irwin' mango as affected by honeybee pollination. Jpn. J. Trop. Agric. 42: 159-162.

Sharma DK and Singh RN, 1970. Self-incompatibility in mango (Mangifera indica L.). Hortic. Res. 10: $108-118$.

Ségeren P, Mulder V, Beetsma J and Sommeijer R, 1996. Apiculture sous les tropiques. Agrodoc 32, $5^{\text {ème }}$ édition Agromisa, Wageningen.

Singh LB, 1960. The mango: botany, cultivation, and utilization, chap 3. Interscience Publishers, New York, USA. pp 42-43.

Singh Z, Malik AU and Davenport TL, 2005. Fruit Drop in Mango. Horticultural Review, 31. John Willey and Sons, Inc., UK.

Siqueira KMM, Kiill LHP, Martins CF, Lemos IB, Monteiro SP and Feitoz EA, 2008. Comparative study of pollination of Mangifera indica L. in conventional and organic crops in the region of the
Submédio São Francisco valley. Rev. Bra. Frutic. 30: 303-310.

Spencer JL and Kennard WC, 1955. Studies on mango (Mangifera indica L.) fruit set in Puerto Rico. Trop. Agric. 32: 323-329.

Sung IH, Lin MY, Chang $\mathrm{CH}$, Cheng AS and Chen WS, 2006. Pollinators and their behaviors on mango flowers in southern Taiwan. Formos. Entomol. 26: 161-170.

Usman M, Fatima B and Jaskani MJ, 2001. Review breeding in mango. Int. J. Agric. Biol. 3: 522-526.

\section{Contribution of Authors}

Azo'o Ela M: Conceived the idea, reviewed literature and edited manuscript

Bouba AB: Collected and analyzed data and wrote the first draft of the manuscript

Djenatou P: Substantially contributed to field works and data collection \& analysis

Fohouo FNT: Reviewed and edited the manuscript and gave final approval 